\title{
Enhancement of Aircraft Flights in the Ash Polluted Sky by Electrostatic Filter
}

\author{
Zare Shahneh A* \\ Cranfield University, UK \\ *Corresponding author: Zare Shahneh A, Cranfield University, UK
}

Submission: 監 November 28, 2018; Published: 眥 December 19, 2018

\begin{abstract}
Thousands of flights were banned and millions of people have affected in Europe in 2010. This was the first natural event which caused a wide and long flight ban in the world, the biggest shut down after Second World War.

The damage in European countries is estimated as figure as billions of Dollars and in particular, a damage of 10 million Pounds a day was estimated for Britain. Because of the volcanic event and its development, aviation authorities of European countries decided to restrict the use of airspace, progressively as the ash cloud was spreading. From April $15^{\text {th }}$ to May $21^{\text {st }}$ were restricted airspace, airports were closed, flights canceled and passengers repressed, so it became the longest period of inactivity in air traffic after the second world war. International Air Transport Association (IATA) estimated losses of 1.1 billion pounds, affecting 1.2 million passengers per day which accounted for $29 \%$ of world aviation. The Airport Operators Association (AOA) estimated losses of 80 million pounds in six days and a half, for a total of 100,000 flights canceled.

Volcanic eruptions are different each one, as to which its style determines the chemistry, physical and chemical components, and particle size of volcanic ash. During an eruption, the lava can flow slowly like a thick liquid (Efussive) or may be accompanied by ash and gases (Explosive). Explosive eruptions pose the greatest risk to aviation because they are always accompanied by ash production. Shafil system is in the process of design and integration to mitigate the intake ash into aircraft engine. It generates a negative electric field to ionize gas around, so that the dust particles receive the negative charge then be carried to a surface with an opposite polarity, and eventually be collected for packing.
\end{abstract}

\section{Introduction}

On $20^{\text {th }}$ March 2010 the Iceland Volcano was erupted and continued for 3 weeks for the first time. Thousands of flights were banned, and millions of people have affected in Europe [1-4]. This was the first natural event which caused a wide and long flight ban in the world, the biggest shut down after Second World War. The damage in European countries is estimated as figure as billions of Dollars and in particular, a damage of 10 million Pounds a day was estimated for Britain. After few days, the new safety rules are announced to overcome the damages: if the ash particles are less than 2 milligram per cubic meter, the aircraft is allowed to fly.

Research to avoid these encounters effect was due to three great volcanic eruptions around the world, such as a Galunggung volcano in Java 1982, Rebdout volcano in Anchorage 1989. 1990 and Mount Pinatubo volcano in the Philippines 1991 [5]. Recently the most important encounter with volcanic ash cloud was produced by the Iceland volcano Eyjafjallajökull 2010, which caused interference in air traffic over EU and economic losses. In $24^{\text {th }}$ June 1982, Galunggung volcano: Sulfur odor and a heavy dust were noted by the British Airways Crew. The aircraft was onto the Indonesian airfield, about 37,000 ft altitude, when all four engines lost power until flameout [6]. The aircraft descended to $12.500 \mathrm{ft}$ altitude, when the pilot could restart the engines. An engine shut off again, and the crew had to do an emergency landing in the Jakarta airport. On the surface of compressor and turbine blades a solidified volcanic ash layer was found. It was found that under this layer the blades were eroded [7]. The ash affected wing leading edge, cockpit windshield, pitot tubes, and contaminated the fuel tanks, and the air and oil systems.

15 December 1989, Rebdout volcano: a Boeing 747-400 was descending for landing in Anchorage, Alaska, encountered a volcanic ash cloud. Attempting to climb out of the ash cloud, and after have gained $3000 \mathrm{ft}$ altitude, all four engines were shut off [8]. Engines 1 and 2 were restarted at $17,000 \mathrm{ft}$, and at 13,000 ft, engines 3 and 4 were restarted. Damages were estimated at $\$ 80$ million because of, none all four engines were airworthy and were replaced, as well as, Pitot static probes, all leading edge areas, VHF antennas, windshield, cockpit and cabin windows, owing to the erosion. Also, the ash polluted oil, hydraulic fluids and fuel [9-11].

15 June 1991, Mount Pinatubo volcano: to the volcanic eruption was joined by a typhoon, which caused a spread quickly the volcanic ash, producing many encounters in one day [12]. The most important and detailed encounter was with a Boeing 747, at $29.000 \mathrm{ft}$ altitude, about 1,100 km away from the volcano. The crew reported a short circuit odor and a thin fog throughout the aircraft. 
The ash produced damages in both windshield and cabin window, all pitot tubes, on the wing and stabilizers, as well as cooling holes from nozzle guide vanes were clogged [13].

These are not the only in-flight encounters that have been presented. Many others the same or less severity have been reported, as those caused by the St Helens Mount volcano in 1980, or by the

Table 1: Encounter severity index, ICAO 2007.
Sakura-jima volcano on several times (1977-82-86-91-94). In the most complete compilation of in-flight encounters, Casadevall [3], have registered at least 129 encounters occurred from 1953 to 2009. It has been possible to complete this compilation, due to encounter reports of the crews, and technical inspection data after the flight [14].

\begin{tabular}{|c|c|}
\hline Class & Criteria \\
\hline 0 & $\begin{array}{r}\text { Sulfur odor noted in cabin; Electrostatic discharge (St. Elmo's fire) on windshield, nose, or engine cowls; Ash reported or suspected by flight } \\
\text { crew, but no other effects or damage noted; Anomalous atmospheric haze observed. }\end{array}$ \\
\hline 1 & Light dust observed in cabin; Fluctuations in exhaust gas temperature with return to normal values; Ash deposits on exterior of aircraft. \\
\hline 2 & $\begin{array}{c}\text { Heavy cabin dust; Contamination of air handling and air conditioning systems requiring use of oxygen; Abrasion damage to exterior surfaces, } \\
\text { engine inlet, and compressor fan blades; Pitting, frosting, or breaking of windscreen or windows; Minor plugging of pitot-static system, insuf- } \\
\text { ficient to affect instrument readings; Deposition of ash in engine. }\end{array}$ \\
\hline 3 & $\begin{array}{r}\text { Vibration or surging of engine(s); Plugging of pitot-static system to give erroneous instrument readings; Contamination of engine oil or } \\
\text { hydraulic system fluids; Damage to electrical or computer systems; Engine damage. }\end{array}$ \\
\hline 4 & Temporary engine failure requiring in-flight restart of engine \\
\hline 5 & Engine failure or other damage leading to crash \\
\hline
\end{tabular}

In all these encounters above were reported by crews a phenomenon named St. Elmo's fire appeared, which is a current of electrons produced by the discharge of the electric field of an object in an environment, such as produced in a thunderstorm or volcanic eruption [15]. The encounters always affect the airframe, performance and operation of aircraft in different ways letting a trace on them, this has allowed the International Civil Aviation Organization (ICAO) to set different criteria to classify, according to crew reports and aircraft findings, the encounter severity. The Table 1 shows this classification.

However, many reports do not have data enough to be classified therefore, are assigned in a special field (Isufficient Data). Table 2 lists the number of encounters produced by each class. Fortunately, encounters between aircraft and volcanic ash, have not led to accidents involving passenger deaths. The 3-4 classes, have produced

\section{Methodology Survey}

Nature of volcanic ash

$20.15 \%$ of encounters with significant damages, while $50 \%$ of all encounters, and have been classified in classes 1-2, letting small traces or minor damages on aircraft [16]. In 1991, due to the Pinatubo volcano eruption, the encounters average increased to more than two per year.

Table 2: Number of aircraft encounters to 2010.

\begin{tabular}{|c|c|}
\hline Class & Number of Encounters \\
\hline 5 & 0 \\
\hline 4 & 9 \\
\hline 3 & 17 \\
\hline 2 & 53 \\
\hline 1 & 12 \\
\hline 0 & 23 \\
\hline ISD & 15 \\
\hline
\end{tabular}

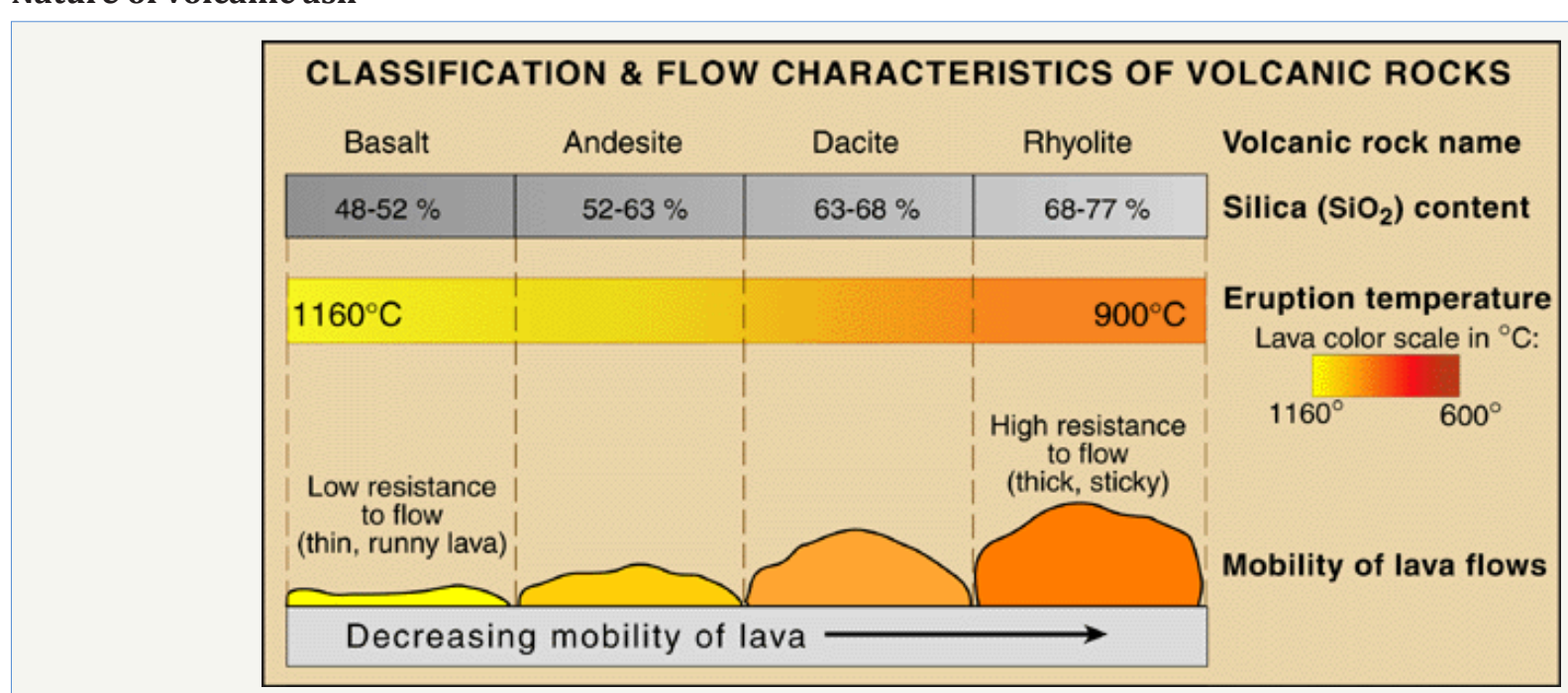

Figure 1: Classification of volcanic rocks [25]. 
A volcano is an opening in the earth's surface through which gases, Tephra (set of particles of different sizes, produced in a volcanic eruption) and molten rock (magma), flows from the center of the earth to the surface, during an eruption. Cooling and solidification of magma is known as igneous rocks. If cooling occurs quickly in the earth's surface, form fine grains (Extrusive Igneous Rocks) or if the cooling is slow, below the crust, crystallize in large grains (Intrusive Igneous Rocks) [17] (Figure 1).

Extrusive igneous rocks are the source of volcanic ash: volcanic material (rocks, minerals and glass) by the effect of gases during an explosive eruption, is broken into fine pieces less than $2 \mathrm{~mm}$ in diameter and cooled by contact with the air [18]. The chemical composition of volcanic material, mainly silica, determines its viscosity, shape and speed of solidification.

The amount of silica $\left(\mathrm{SiO}_{2}\right)$ contained in the volcanic rock (generally more than 50\%) controls the volcanic ash produced. Composed of one silicon molecule and two oxygen molecules, silica is one of the main elements found in the crust (Quartz is a form of silica), characterized by high hardness, to be very abrasive and a high melting point. Silica does not conduct electricity, so is used as the basis for glass and ceramics. Extrusive igneous rocks, according to the concentration of silica found, provide a classification into four types: Basalt, Andesite, Dacite and Rhyolita. In Figure 2, is clearly shown as the variation in the concentration of silica affects the movement of volcanic material to the atmosphere, and can eventually cause an explosive eruption, with high production of volcanic ash.

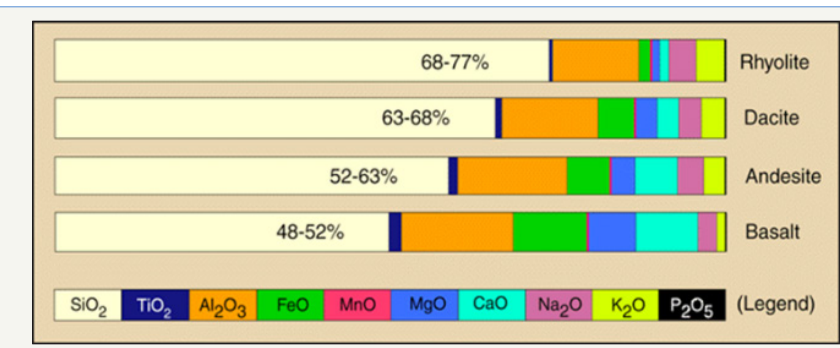

Figure 2: Volcanic rock components [25].

In Rhyolite type, the concentration of silica, sodium and potassium increases, cause a reduction in the concentration of calcium, iron and magnesium, and so its melting point is low. Otherwise, it happens for the Basalt type, in which the concentration of calcium, iron and magnesium increases, reduces the percentage of silica, sodium and potassium, and the melting point would be higher. Andesite and Dacite types are sub-classified as intermediate. Many other components found in the volcanic rocks are shown in the bar graph below, including average concentration for Titanium Dioxide, Aluminum Oxide, Iron Oxide, Manganese Oxide, Magnesium Oxide, Calcium Oxide, Sodium Ocide, Potasium Oxide and Phosphorus Pentoxide (Figure 3).

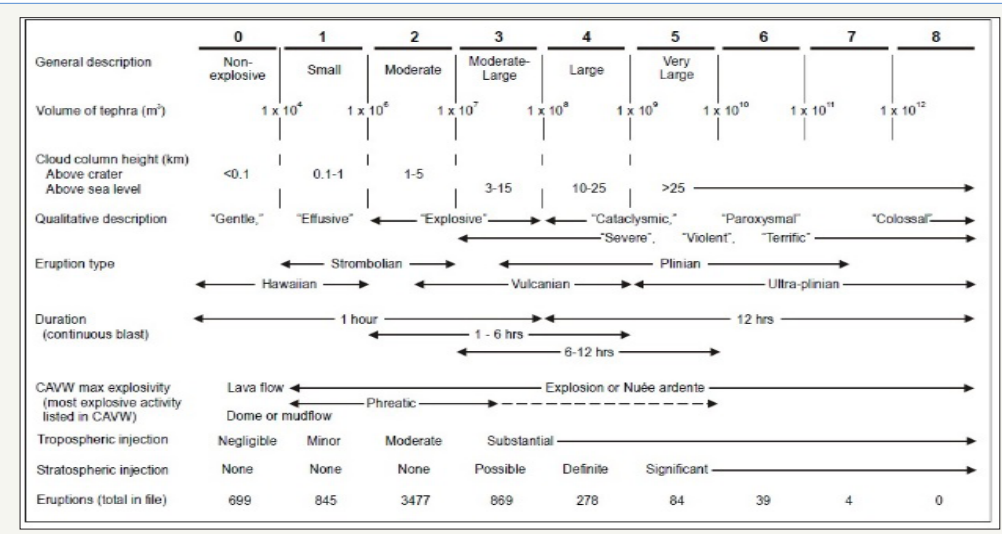

Figure 3: Volcanic explosivity index, ICAO 2007.

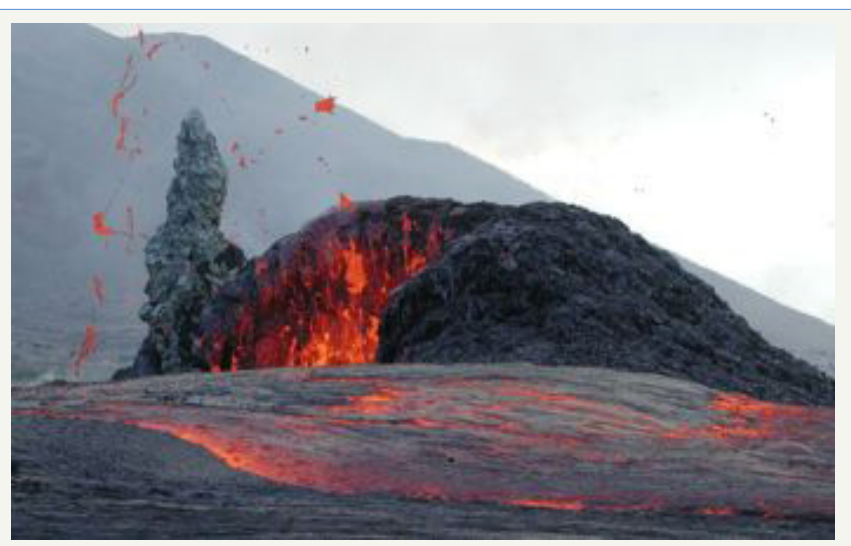

Figure 4a: Gentle effusive eruption (basalt magma) Hawaiian-style eruption

According to above, volcanic eruptions are different each one, as to which its style determines the chemistry, physical and chemical components, and particle size of volcanic ash. During an eruption, the lava can flow slowly like a thick liquid (Efussive) 
or may be accompanied by ash and gases (Explosive) [11,19]. Explosive eruptions pose the greatest risk to aviation because they are always accompanied by ash production. The amount of ash produced - measured in terms of volume - during an eruption, as well as the height reached, and other features, allow to classify explosive eruptions in types: Hawaiian, Strombolian, Vulcanian and Plinian. Figure 4 shows the criteria considered for Volcanic Explosivity Index (VEI) to classify the type of eruption.

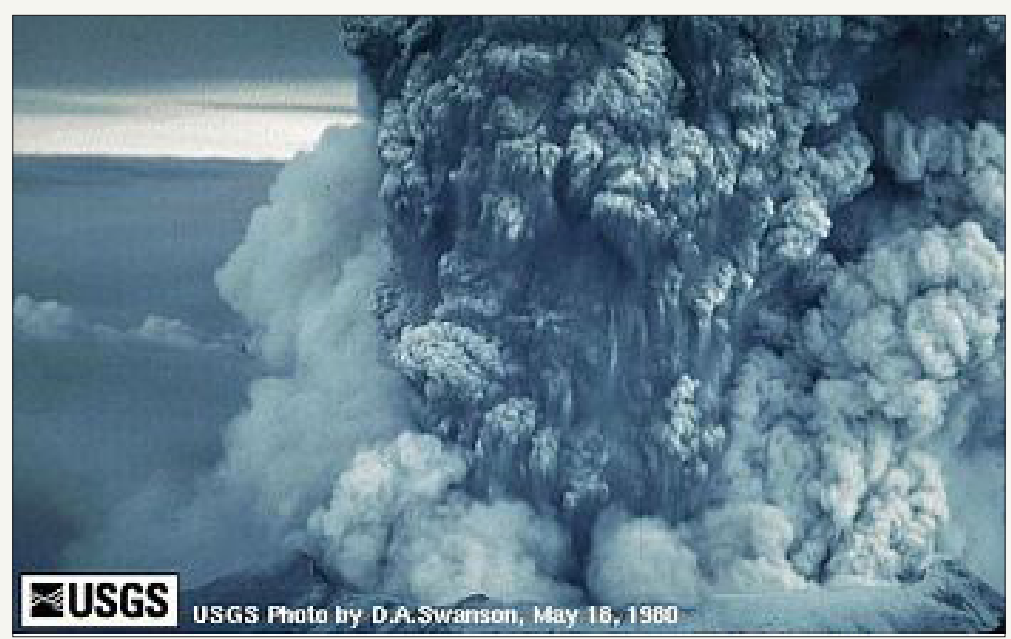

Figure 4b: Explosive eruption (dacite and rhyolite magma) Plinian-style eruption.

An example of the Hawaiian eruption type, is Kilauea volcano which constantly is throwing lava flows with low amounts of ash and gases [20]. The main example of a Plinian eruption was Mount Pinatubo in 1991 that yielded about $10 \mathrm{~km}^{3}$ of ash. The Icelandic volcano Eyjafjallajökull eruption was classified as Vulcanian type, throwing ash plumes between 10-25km height.

Inside the Earth, due to the interaction of water and molten rock, a large amount of gases are released, thus forming small bubbles. These are kept inside the magma because of the high pressure. When the magma finds a way out (volcano) [21], flows to the surface where the pressure is lower and the gases expand. The increase in volume of the gases released, fragments the magma forming the tephra. In addition to the viscosity (the amount of $\mathrm{SiO}_{2}$ ) and temperature of magma, the volume attained by the expanding gases determines whether an eruption is effusive or explosive.

The main gases released are water vapor $\left(\mathrm{H}_{2} \mathrm{O}\right)$, carbon dioxide $\left(\mathrm{CO}_{2}\right)$ and sulfur dioxide $\left(\mathrm{SO}_{2}\right)$. Lesser amount of other gases emerges, such as hydrogen sulfide $\left(\mathrm{H}_{2} \mathrm{~S}\right)$, hydrogen $\left(\mathrm{H}_{2}\right)$, carbon monoxide ( $\mathrm{CO}$ ), hydrogen chloride $(\mathrm{HCl})$ and hydrogen fluoride (HF). These components adhere to the particle surface tephra (ash) in the form of droplets containing salts and moisture [22]. By themselves, the released gases are not harmful to aircraft, but when mixed with water vapor is converted into other substances. $\mathrm{SO}_{2}$ is diluted in water vapor, forming sulfuric acid molecules and the same as $\mathrm{HCl}$ and $\mathrm{HF}$, which falls as acid rain.

These substances are corrosive and conductive, causing damage to the engine, the windshield pitting, oxidizing the skin and contaminate all places where they can enter. That represents irreparable damage and costly, in terms of operation and maintenance for aircraft and industry, at short or long term. Due to the acid drops and collision of ash particles, are presented electrical phenomena in the ash clouds. This is a sign that the aircraft has encountered an ash cloud, observing lightnings and St Elmos fire
[23]. Because of the high electrostatic charging of aircraft in an ash cloud, there are interferences in communications, even losing them completely. The electric charge potential of volcanic ash clouds can range from $3 \mathrm{kV} / \mathrm{m}$ and $10 \mathrm{kV} / \mathrm{m}$, as illustrated by the ICAO 2007 .

\section{Meteorological observation}

Although prediction in a long-term of volcanic eruption is not possible, in some way is possible predict them based into the constant volcanoes monitoring. For this purpose, the States around the world have established Volcanological and Meteorological Centers, enabling act at the right time according to the disaster response plan, if an eruption is in progress [24]. This monitoring lends a hand to the world aviation to know the volcanoes condition and their activities.

The records of a volcano activity, in terms of seismic activity, induced for the gases and magma movement within it, let consider an eruption forecast in the short term. Set with this McNutt [20], on the principle that every action has a reaction of equal magnitude and in the opposite, the ratio between the amplitude of the recorded movements of the volcano and the height reached by the ash column or VEI. In the study of eruptions under this ratio, was found that if the seismic activity reaches critical amplitude, the probability to occur an explosive eruption is between 60$80 \%$ [25]. However, volcanic tremors did not always end in an eruption, so 20 to 40 percent were false alarms. Volcanic eruptions are unpredictable, are the result of the dynamism of nature that shows how powerful it can be and confirms that it is not within human reach to contain them. It is possible to join multidisciplinary efforts in the prevention of the encounters. For this reason, the International Civil Aviation Organization (ICAO), emphasizes the importance of communication between pilots, air traffic controllers, meteorological and volcanically observatories, and airlines.

To avoid aircraft-volcanic ash encounter has been established an Initial Danger Area (IDA) for two eventual moments, according 
to the information about the volcanic event. The first one while has not occurred the eruption, IDA is defined like a circle of $222 \mathrm{~km}$ radius, on the zone where may be presented, centered on the likely source; and the second one it has already occurred, with the information of eruption and winds over it, IDA will center next to the source in downwind with $111 \mathrm{~km}$ radius [26]. The purpose of this zone is to maintain the safety of aircraft, likewise there is no air traffic in a polluted area. However, when is found the volcanic ash cloud by meteorological centre, measurements are made of its concentration, trying to define the area dimensions polluted. In this way, areas are classified due to contamination level, such that suggested in the Volcanic Ash Contingency Plan EUR and NAT Regions 2010:

a) Area of Low Contamination: airspace with volcanic ash concentrations equal to or less than

\section{$2 \times 10^{-3} \mathrm{~g} / \mathrm{m}^{3}$.}

b) Area of Medium Contamination: airspace with volcanic ash concentrations greater than $2 \times 10^{-3} \mathrm{~g} / \mathrm{m}^{3}$, but less than $4 \times 10^{-3} \mathrm{~g} / \mathrm{m}^{3}$.

c) Area of High Contamination: airspace with volcanic ash concentrations equal to or greater than $4 \times 10^{-3} \mathrm{~g} / \mathrm{m}^{3}$.

The classification of polluted areas allows to fix the limits, both horizontal and vertical for aircraft operations, based on concentration and dispersion measurements because of the wind effect onto the ash cloud. Although above, in the United Kingdom the Civil Aviation Authority 2012 ensures that in low contamination areas is safe to fly, and for areas of medium or high contamination will need to have a safety case approved.

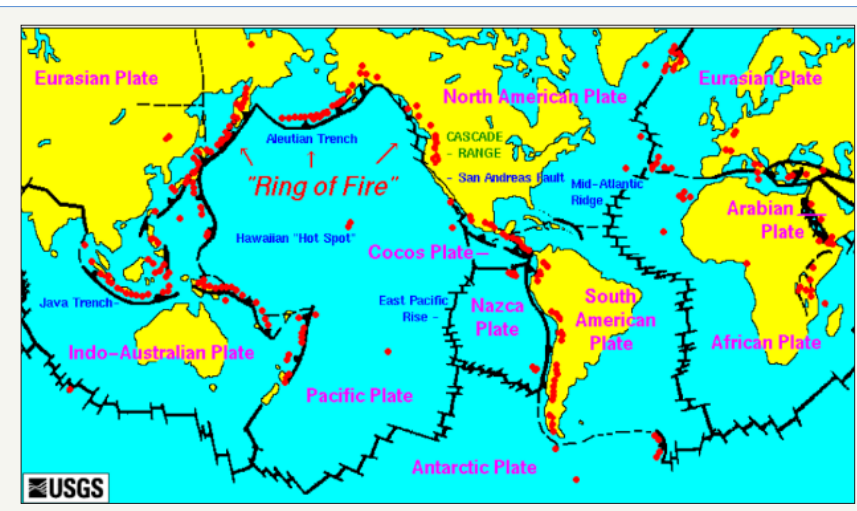

Figure 5: Volcanoes location.

Volcanoes around the world, are on the Ring of Fire principally, are located over west edge from South, Central and North of America, across the Aleutian Islands, from there goes down across Japan, Philippines and Malaysia, to return to the South Pacific throughout Papua New Guinea and New Zealand. Figure 5 shows all the volcanoes location.

\section{Result and discussion}

\section{Damages to aircraft}

It has been revived that immediate damages caused as well as longer time damages due to volcanic ash intake to aircraft engine.
Whenever an aircraft flies across a volcanic ash cloud will get great damage over the skin, airframe and engines. "Damage in excess of one quarter of a billion dollars has been directly linked to volcanic ash encounters" [27]. The volcanic ash may cause costly damages to the world aviation, can be related to its abrasive, obstructive and highly contaminating characteristics.

Abrasive: the hardness, concentration and shape of the volcanic ash can reduce the efficiency of engine compressor blades (especially high pressure compressor) due to eroding surface, hence can cause loss of the high pressure turbine and engine thrust. The abrasion is a permanent damage on the compressor blades. Also, the volcanic ash can erode cockpit windows, leading edge areas, Pitot static probe, antennas and all aircraft surfaces.

Obstructive: melting point of the volcanic ash is bellow of operating temperatures, this mean that the volcanic ash melts in the combustion zone increasing the static burner pressure because of clog the cooling holes. Passing through the turbine zone where operation temperatures are lower than combustion zone, volcanic ash melted sticks and solidified on the high pressure vanes and turbine blades surface [4,6]. Finally, turbine cannot expand the combustion gases, compressor pressure increase and a surge can be produced in the engine, causing thrust loss or engine flame out. Also, can clog the cooling ducts of compressor blades, conditions that increase fuel consumption and operation temperature.

Contaminating: volcanic ash is characterized by high acid content, which causes damage to the aircraft. The air passing through the engines is used by the Environmental Control System (ECS) to control the temperature and pressure within the aircraft. ECS needs to be operational mode throughout the flight, to provide to the passengers, crew and avionics equipment a comfortable environment (Air-conditioning, cabin pressurization, breath air, etc.) at different altitudes [28]. The air used by the ECS is a bleed air from the engines, and when an encounter between an aircraft and a volcanic ash cloud occur, both passenger and cockpit cabin are contaminated. A complete cleaning is necessary of air conduct and filters, cockpit instrument panel, passenger and baggage compartments, circuit breakers. Additionally, can be contaminated fuel and oil systems because of the ash may go through very small places, necessitating a complete fluid and filter replacement.

Figure 6 shows pressure and temperature distribution in a Rolls Royce Trent 800 engine operating in normal conditions in the High Pressure Compressor (HPC) are reached 40 atmospheres pressure, at the exit of the combustion chamber there is always a pressure drop of 5\%. Figure 7, Time history of engine parameters during dust experiments, shows the results of experiments where the design conditions are represented by the timeline 0 . By ingestion of ash in the engine during 5 minutes altered design conditions and increases the compression ratio 1.3 in the HPC $(\sim 30 \%$ increase pressure) and 1.4 in the combustion chamber $(\sim 40 \%$ increase pressure) on the design parameters. It also shows a small increase in fuel consumption and in the ratio of the fan pressure as a result of increase in the pressure distribution in all stages of the motor. 


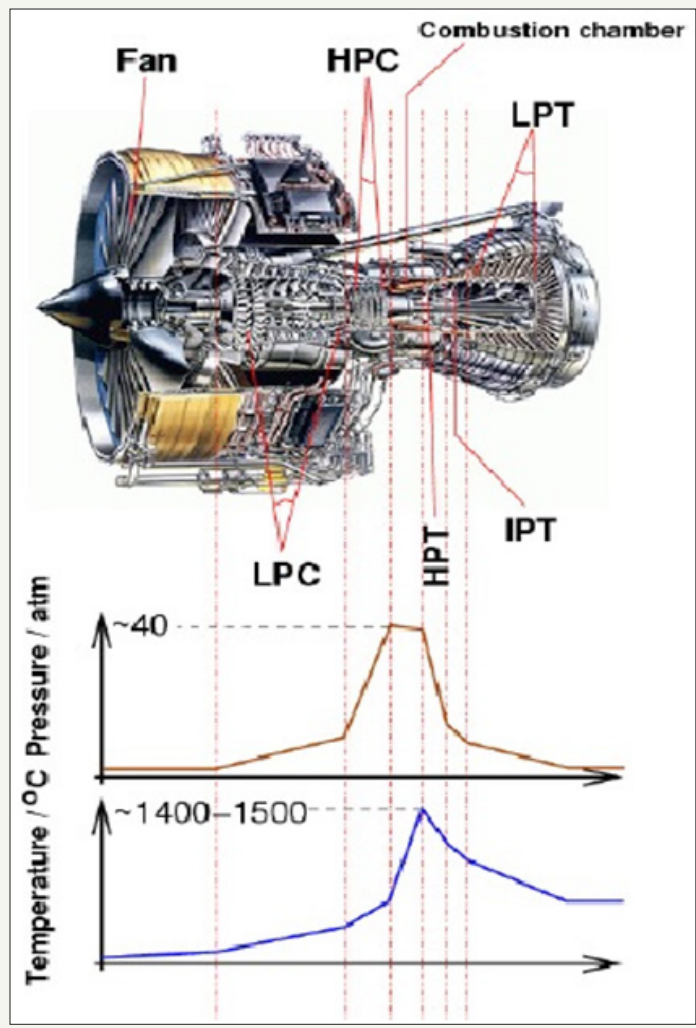

Figure 6: Pressure and temperature distribution in a rolls royce trent 800 engine operating in normal conditions.

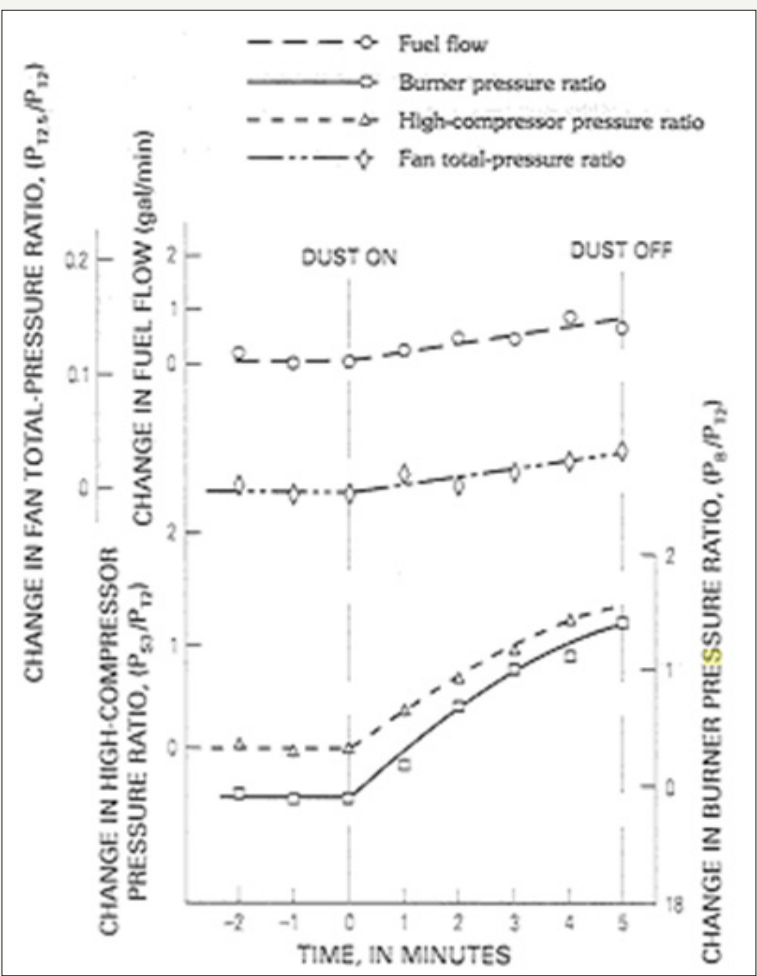

Figure 7: Time history of engine parameters during dust experiments.

\section{Case study: Eyjafjallajökull volcanic eruption}

This chapter of aviation history began to be written a year before the main eruption, by the beginning of seismic activity of the volcano in March 2009. The activity within the volcano continued in the following months, becoming more frequent and intense between December 2009 and March 2010. Because of that the first eruption of low explosive (VEI $=1$ ) was presented on March $20^{\text {th }}$, which eventually was named as the first phase of the Eyjafjallajökull volcano eruption. 


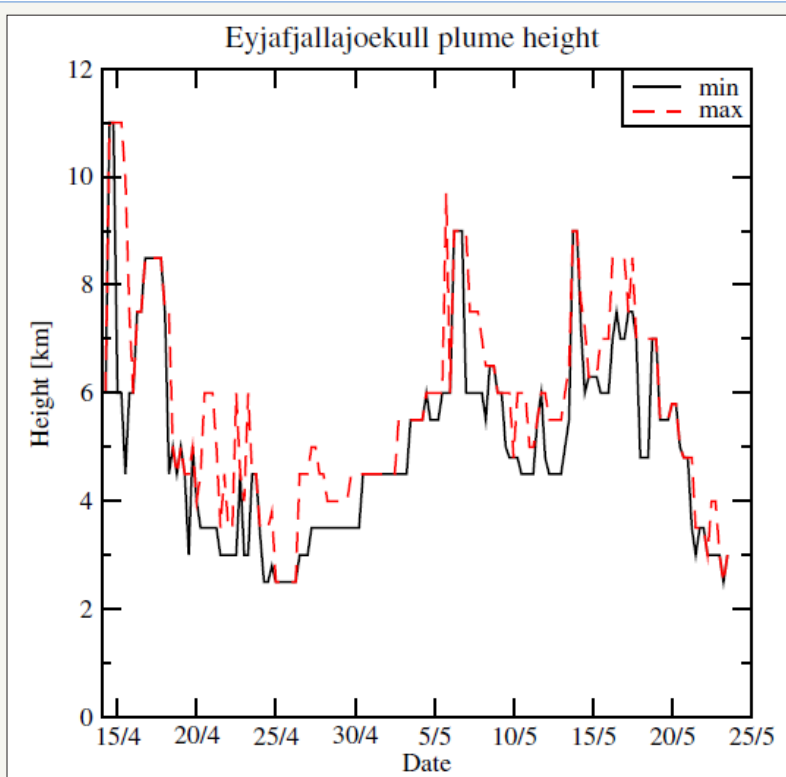

Figure 8: Profile of altitude reached by the cloud of volcanic ash thrown up during the eruption of Eyjafjallajökull volcano.

The so-called second phase of the eruption, which began on April $14^{\text {th }} 2010$, reached a VEI of 4 throwing large amounts of lava, gases and ash-rich glass. As a result of the explosive eruption an ash cloud rose and reached an altitude of $11 \mathrm{~km}$, as shown in Figure 8 (Langmann [8]). Islandic Met-Office estimated that during the first three days of eruption 140 million $\mathrm{m}^{3}$ of tephra were thrown by the volcano, at an average discharge about $300 \mathrm{~m}^{3} / \mathrm{sec}$. Meanwhile, the Institute of Earth Sciences in Iceland collected samples of material ejected, finding large concentrations of Fluor, and fine ash grains as follows: $24 \%$ smaller than 10 microns, $33 \%$ between 10 to 50 microns, 20\% between 50 to 146 microns, and 23\% between 146 to 294 microns.

With the collected samples was carried out an analysis of the ash thrown during eruption to obtain a detailed profile of the composition as shown in Figure $4 \mathrm{a} \& 4 \mathrm{~b}$. Based on the chemical content of the samples, it was found that the volcano ejected balsaltic-andesitic lava type, with an intermediate percentage of silica (58\%). Furthermore, was also analyzed the development of the eruption and the ash produced to determine the factors involved in the dispersion in atmosphere.

Polar jet stream: this is an air current that runs through the earth around the Arctic Circle, across North America, Asia and some European countries, reaching speeds of $160 \mathrm{~km} / \mathrm{h}$ does not have a stable direction, and passes very close Iceland. The eruption had enough power to reach the altitude of the Jet Stream, whereby the ash was so wide dispersion, in addition to the Jet Stream took an unusual stable path to the south-east just as the eruption began [29].

Glacier: being one of its main features, this volcano is surrounded by a large layer of ice hence it is known as Island Mountain Glacier. Because the eruption took place 200 meters below the glacier, the ice was melted and found ways to flow into the volcano. This in turn led to increased water vapor in the wash, and as explained earlier in this document increased its level of explosivity. Moreover, the melting ice caused the rapid cooling of the lava, creating a cloud of very fine ash and highly abrasive (Figure 9).

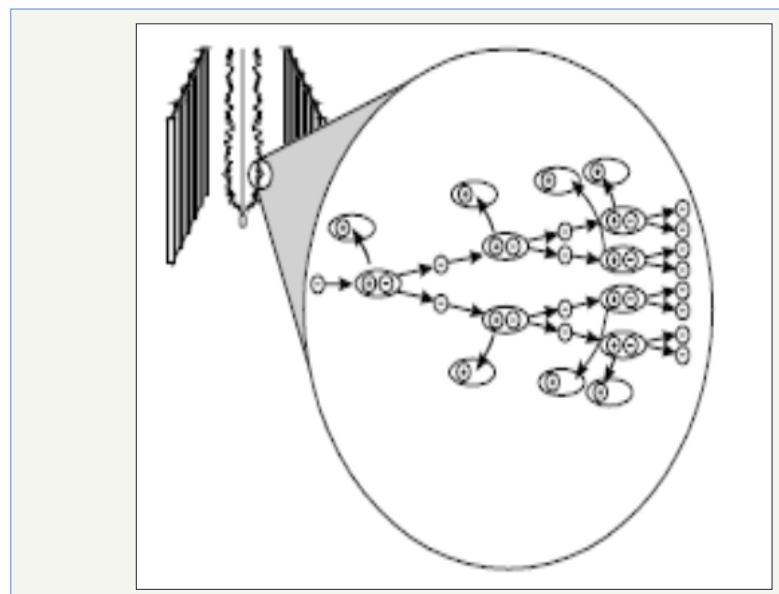

Figure 9: Avalanche multiplication.

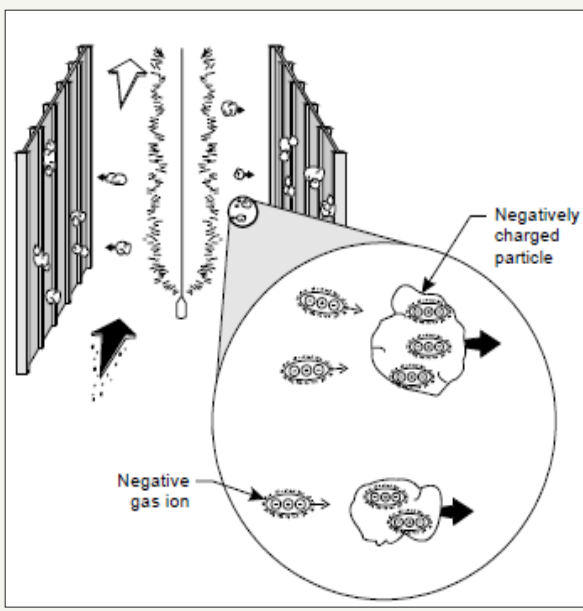

Figure 10: Particles migration.

Without the combination of these two factors, the Eyjafjallajökull volcano eruption could have been of average size, and had 
not reached the airspace in Northern Europe. Because of the volcanic event and its development, aviation authorities of European countries decided to restrict the use of airspace, progressively as the ash cloud was spreading. From April $15^{\text {th }}$ to on May $21^{\text {st }}$ were restricted airspace, airports were closed, flights canceled and passengers repressed, so it became the longest period of inactivity in air traffic after the Second World War. Although there was no major damage to aircraft or airports due to the volcanic ash, because of inactivity the International Air Transport Association (IATA) estimated losses of 1.1 billion pounds, affecting 1.2 million passengers per day which accounted for $29 \%$ of world aviation. The Airport Operators Association (AOA) estimated losses of 80 million pounds in six days and a half, for a total of 100,000 flights canceled. Finally, in October 2010 the meteorological authorities established that the eruption had ended completely, and the volcano had no reports of activity inside (Figure 10).

\section{Design of shafil system}

The basic principle of operation of an electrostatic filter (also known as precipitator), is to generate a negative electric field to ionize gas around, so that the dust particles receive the negative charge then be carried to a surface with an opposite polarity, and eventually be collected for packing. All this happens in several steps due to different elements described below:

Discharge electrode: Are thin wires of approximately $0.25 \mathrm{~cm}$ in diameter, usually made of stainless steel, titanium alloys, aluminum or copper. They are usually suspended from a frame in the top of the filter, and at the bottom are attached to a guide frame to keep them aligned. Some manufacturers of electrostatic filters used plates instead of wires as discharge electrodes.

Collection electrodes: Plates are used, due to the need for high efficiency in collecting particulates, are made of carbon steel, alloy steel or stainless steel, from 0.05 to $0.2 \mathrm{~cm}$ thick. Tubes are also used as collection electrodes, mainly when using sprays to remove the collected particles.

Voltage supply: Provides the energy necessary to control the electric field between discharge and collection electrode. This system consists of an automatic control voltage, a voltage transformer, a high voltage rectifier, sensing device, and voltage control. The system connects to voltage Electrode Discharge through a BUS LINE.

Rappers: removal of the particles is responsible for this system designed to maintain strength and frequency depending on the operating conditions. For this process, various methods are used as hammer/ anvil, magnetic impulse, tumbles hammers or electric vibrators, the latter to remove the dust that accumulates on the discharge electrode.

Hoppers: is a device which drops the dust is removed from the collection electrodes and temporarily stored. The design is made so that the particles fall freely to the bottom of the device, due to its sides have a slope of 50 to $70^{\circ}$ and can be carried to its final destination.
Shell: is the structure that supports and maintains protected to the above elements and forms the filter. Is usually made of carbon steel with a thickness of 0.5 to $0.6 \mathrm{~cm}$. The filtering process begins with the generation of a negative electrical field around the discharge electrode, through a high dc voltage. The increase of the voltage applied to the wires generates an area known as corona discharge, where electrons are released. Those free electrons are repulsed by the negative electric field move quickly, trying to move away from the discharge electrode, so who collide with gas molecules around. This collision causes the molecules to release an electron, thereby doubling the electrons in the electric field, and the molecules are ionized positively. This process occurs continuously generating more free electrons is known as Avalenche multiplication.

By generation of electrons and positive ionization of the gas molecules, free electrons leaving the corona discharge move more slowly in an intermediate zone between the discharge and collection electrode, because of this, the electrons are added to the gas molecules in the intermediate zone, thereby forming negative ions. The new situation means that the electric field repels negative corona ions formed recently and move slowly toward the collection electrode. On its way, negative ions will adhere to the surface of the particles carried in the air stream, causing it to charge negatively and be drawn toward the positive electric field from the collection electrode. When the particles reach the collection electrode, a part of the load is transmitted to the plate and the other part is retained to maintain the particles adhered.

Thus, is created a layer of dust on the surface of the collection electrode, usually between 0.08 and $1.27 \mathrm{~cm}$ thick, depending on the operation and the amount of contaminated air to be filtered. Finally, the particles retained in the collection electrode are removed by a process known as rapping, which involves vibrating the collecting surface by means of bumps, and thereby the particles falling into the hopper, wherein the particles removed from the air are driven toward the bottom and brought for storage. In some cases, the particulate removal process is done with liquids.

This is the process by which the air is filtered through electrostatic, with an efficiency of 99 percent in particles between 0.01 to 10 microns in diameter. This method is used mainly in the cement industry, chemicals, paper, metal, naval and other, either to avoid the emission of pollutants into the environment, or to keep out contaminated air to the vessel engines. In aeronautics, this type of filtering process is used in the test plants to filter the air that is taken from the atmosphere in an environment considered contaminated. The other hand, there are no references to its use in the configuration of the aircraft engines or in the ECS.

\section{Conclusion}

Volcanic ash is caused a vital damage to flight business. This is a high as 1.1 billion pounds, affecting 1.2 million passengers per day which accounted for $29 \%$ of world aviation, and 10 million Pounds a day for Britain. 


\section{Abrasive}

The hardness, concentration and shape of the volcanic ash can reduce the efficiency of engine compressor blades (especially high pressure compressor) due to eroding surface, hence can cause loss of the high pressure turbine and engine thrust. Melting point of the volcanic ash is bellow of operating temperatures; this means that the volcanic ash melts in the combustion zone increasing the static burner pressure because of clog the cooling holes. Passing through the turbine zone where operation temperatures are lower than combustion zone, volcanic ash melted sticks and solidified on the high pressure vanes and turbine blades surface.

volcanic ash is characterized by high acid content, which causes damage to the aircraft. The air passing through the engines is used by the Environmental Control System (ECS) to control the temperature and pressure within the aircraft. ECS needs to be operational mode throughout the flight, to provide to the passengers, crew and avionics equipment a comfortable environment (Air-conditioning, cabin pressurization, breath air, etc.) at different altitudes. The air used by the ECS is a bleed air from the engines, and when an encounter between an aircraft and a volcanic ash cloud occur, both passenger and cockpit cabin are contaminated.

This is the process by which the air is filtered through electrostatic, with an efficiency of $99 \%$ in particles between 0.01 to 10 microns in diameter. This method is used mainly in the cement industry, chemicals, paper, metal, naval and other, either to avoid the emission of pollutants into the environment, or to keep out contaminated air to the vessel engines. In aeronautics, this type of filtering process is used in the test plants to filter the air that is taken from the atmosphere in an environment considered contaminated. The other hand, there are no references to its use in the configuration of the aircraft engines or in the ECS.

Shafil system is in the process of design and integration to mitigate the intake ash into aircraft engine. It generates a negative electric field to ionize gas around, so that the dust particles receive the negative charge then be carried to a surface with an opposite polarity, and eventually be collected for packing. All researchers are invited to deliver their ideas to develop the ash mitigation system.

\section{References}

1. Andò B, Coltelli M, Prestifilippo M, Scollo S (2011) A Lab-scale experiment to measure terminal velocity of volcanic ash. IEEE Transactions on instrumentation and measurement 60(4): 1340-1347.

2. Casadevall TJ (1993) Volcanic hazard and aviation safety: lessons of the past decade. Flight Safety Digest 12(5): 1-9.

3. Casadevall TJ, Guffanti, Marianne, Budding, Karin (2010) Encounters of aircraft with volcanic ash clouds: A compilation of known incidents, 1953-2009. US Geological Survey Data Series 545, pp. 1-26.
4. Dunn MG, Wade DP (1994) Influence of volcanic ash clouds on gas turbine engines: in Volcanic ash and aviation safety: Proceedings of the first international symposium on volcanic ash and aviation safety. US Geological Survey Bulletin B 2047, pp. 107-117.

5. Elgalad ML (1978) Design of an altitude test plant investigation of mechanical and electrostatic air filter. Cranfield Institude of Technology, School of Mechanical Engineering, UK.

6. http://feww.wordpress.com/2010/04/20/eyjafjallajokull-erupting$\%$ E2\%80\%93-update-20-apr/.

7. Fu RQ (2011) Volcanic ash damage on turbine blade. Cranfield University, Advanced Lightweight Structure \& Impact, UK.

8. Langmann B, Folch A, Hensh M, Matthias V (2012) Volcanic ash over Europe during the eruption of Eyjafjallajökull on Iceland. International Journal of Atmospheric Environment, 48: 1-8.

9. http://earthice.hi.is/eruption_eyjafjallajokull_2010.

10. http://www.iata.org/Pages/default.aspx.

11. International Civil Aviation Organization (2009) Manual on volcanic ash, radioactive material and toxic chemical clouds, ( $2^{\text {nd }}$ edn), ICAO, Montreal, Canada.

12. International Civil Aviation Organization (2010) Volcanic ash contingency plan-EUR and NAT Regions. ICAO, Montreal, Canada.

13. http://www.geo.mtu.edu/volcanoes/Volcanoes/Index.html.

14. http://www.volcano.oregonstate.edu/education/gases/index.html.

15. Park C (2001) The environment: principles and applications, $\left(2^{\text {nd }} e d n\right)$, Routledge, New York, USA.

16. Petrucci RH, Harwood WS (1993) General chemistry: principles and modern applications, ( $6^{\text {th }}$ edn), Macmillan, New York, USA.

17. Press, Frank \& Siever, Reymond (2001) Understanding earth, ( $3^{\text {rd }}$ edn), W. H. Freeman and Company, New York, USA.

18. Preston R (2011) Performance degradation effects of volcanic ash on a military engine. Cranfield University, Department of Power and Propulsion. UK.

19. http://www.pnas.org/content/108/18/7307.full.

20. McNutt SR (1994) Volcanic tremor amplitude with volcano explosivity index (VEI) and its potential use in determining ash hazards to aviation: in Proceedings of First International Symposium on Volcanic Ash and Aviation Safety, 1991, US Geological Survey Bulletin 2047, p. 377.

21.http://www.skybrary.aero/index.php/Volcanic_Ash.

22. http://www.nytimes.com/.

23. UK Civil Aviation Authority (2011) Guidance regarding flight operations in the vicinity of volcanic ash. CAA, UK, pp. 1-17.

24. http://www.caa.co.uk/default.aspx?catid=2011\&page type=90.

25. http://www.volcanoes.usgs.gov/images/pglossary/VolRocks.php.

26. http://www.volcanoes.usgs.gov/ash/properties.html.

27. http://www.volcanoes.usgs.gov/hazards/gas/index.php.

28. http://www.epa.gov.

29. http://yosemite.epa.gov/oaqps/EOGtrain.nsf/DisplayView/ SI_412B_0-5? 

(c) (i) Creative Commons Attribution 4.0

For possible submissions Click Here

Submit Article

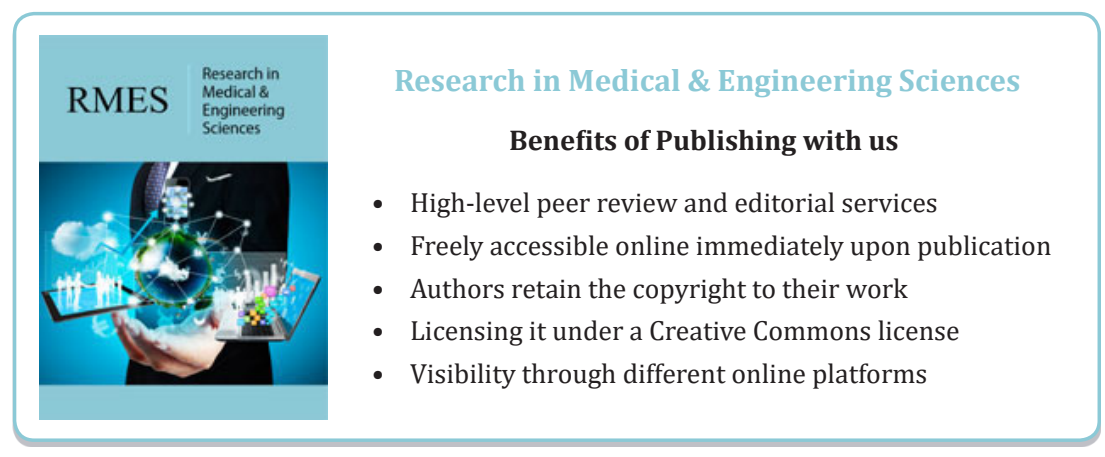

